\title{
İşbirliği Ölçeği: Kültürel Adaptasyon
}

\section{Uzm. Psk. Yağmur Gözde Yerlikaya ${ }^{1 *}$ Dr. Öğr. Üyesi Burak Doğruyol ${ }^{2}$}

Geliş tarihi: 01.05.2020

Kabul tarihi: 30.06 .2020

\section{Atıf bilgisi:}

IBAD Sosyal Bilimler Dergisi

Sayı: $8 \quad$ Sayfa: $350-363$

Yıl: 2020 Dönem: Güz

This article was checked by Turnitin. Similarity Index $2 \%$

Bu makalede araştırma ve yayın etiğine uyulmuștur.

1 İstanbul Üniversitesi, Türkiye, y.gozdeyerlikaya@gmail.com, ORCID ID 0000-0002-8842-4670

2 Altınbaş Üniversitesi, Türkiye, burakdogruyol@gmail.com, ORCID ID 0000-0002-3469-590X

* Sorumlu yazar
ÖZ

$\mathrm{Bu}$ araştırmanın amacı, işbirliğine yönelik kültürel olarak geçerli ve güvenilir bir ölçüm aracı elde etmektir. İşbirlikçi davranışlar, insanlık tarihinden bu yana türün devamını destekleyici nitelikte olagelmiştir. Prososyal davranışların içerisinde tanımlanan işbirliği davranışı, alanyazında sıklıkla özgecilik ile ayrıştırılmadan ele alınmaktadır. Ancak kavramın temel anlamı ve pratiği gereği, işbirliğini özgecilikten ayrıştırarak ele almak ve ölçmek anlamlı görülmektedir. Bu noktada Xie, Yu, Chen ve Chen (2006) tarafindan geliştirilen İşbirlikçilik ve Rekabetçilik Ölçeği'nden yararlanarak işbirliğini ölçmek üzere Türkçe bir ölçek oluşturulması hedeflenmiştir. Ölçekten çeşitli maddeler seçilmiş ve 16 maddelik Türk kültürüne uyarlanmış İşbirliği Ölçeği elde edilmiştir. 171 kişilik bir örneklemde sınanan İşbirliği Ölçeği, doğrulayıcı faktör analizleri sonucunda kendi içinde tutarlı ve işbirliğini temsil edici 11 maddelik son halini almıştır. İşbirliği Ölçeği aynı zamanda, Alternatif Tutsak İkilemi Oyunu, İşbirliği Olarak Ahlak Ölçeği ve Prososyal Niyet Anketi'nden elde edilen değerlerle pozitif korelasyon göstermiştir. Buna göre, kişilerin İşbirliği Ölçeği ile belirlenen işbirliği eğilimleri yükseldikçe ölçeklerden elde edilen işbirliği davranışları ve özgeci eğilimler yükselmiştir. Dolayısıyla, ölçeğin işbirliği kavramını beklenen şekilde ölçtüğü görülmüştür. Sonuç olarak kültürel adaptasyon çalışması yapılan İşbirliği Ölçeği'nin kişilerin işbirliğine yönelik tutumlarının ve işbirliği eğilimlerinin ölçümünde geçerli ve güvenilir bir ölçek olduğu değerlendirilmiştir.

Anahtar Kelimeler: İşbirliği Ölçeği, İşbirliği, İşbirlikçilik ve Rekabetçilik Ölçeği 


\section{Cooperation Scale: Cultural Adaptation}

\begin{abstract}
MA. Yağmur Gözde Yerlikaya ${ }^{1^{*}}$ Assist. Prof. Dr. Burak Doğruyol ${ }^{2}$
\end{abstract}

First received: 01.05 .2020 Accepted: 30.06 .2020

\section{Citation:}

IBAD Journal of Social Sciences

Issue: 8

Pages: $350-363$

Year: 2020 Session: Fall

This article was checked by Turnitin. Similarity Index $2 \%$

\section{${ }^{1}$ Istanbul University, Turkey, y.gozdeyerlikaya@gmail.com,} ORCID ID 0000-0002-8842-4670

2 Altınbaş University, Turkey, burakdogruyol@gmail.com, ORCID ID 0000-0002-3469-590X

\section{* Corresponding Author}

\begin{abstract}
Current study aimed to achieve a culturally reliable and valid cooperation measure. Cooperative behaviors are assumed to have a survival value. Prosocial behaviors and cooperative behaviors have been used interchangeably in the relevant literature. Yet, it is important to disentangle cooperation and prosocial behaviors to study each in isolation and to develop measurement tools. Current study aimed to form a reliable and valid scale to measure cooperation in Turkish. For this aim, Cooperation and Competition scale developed by Xie, Yu, Chen, and Chen (2006) was used. By using relevant items from the scale and a culturally relevant item, a 16-item cooperation scale was created. Participants $(N=171)$ fulfilled the Cooperation scale, Prosocial Intentions Scale, Morality as Cooperation Scale (MAC), and Alternative Prisoner's Dilemma. Results of the confirmatory factor analyses revealed a 11-item valid Cooperation scale. Cooperation scores derived from the final form of Cooperation scale showed significant positive correlations with prosocial intentions, subdimensions of morality measured by MAC. Besides, cooperative participants in prisoner's dilemma scored higher on Cooperation scale as compared to competitive participants. Overall, results supported that Cooperation scale is a valid and reliable measure to test the cooperative attitudes and intentions.
\end{abstract}

Keywords: Cooperation Scale, Cooperation, Cooperativeness and Competitiveness Scale 


\section{GİRIŞ}

İnsanlar sosyaldir; birbirleriyle birlikte var olurlar, birbirlerine yardım ederler, birlikte çalışırlar, gruplar oluştururlar ve işbirlikleri kurarlar. Canlıların birbirlerine yardım etmeleri ve işbirliği kurmaları uzun zamandır araştırılan ve temelleri incelenen konulardandır. Yalnızca en karmaşık canlı olan insanda değil, doğada en basitinden en karmaşığına birçok canlıda bu davranışların ortaya çıktığı görülebilir (West, Griffin ve Gardner, 2007). Beslenmek için avlanan aslanlar veya kendilerini grupça savunan kurtlar gibi doğal ortamda birçok canlı hayatta kalmak için ve canlılığını daha az enerji sarf ederek sürdürebilmek için işbirlikleri kurmaktadır.

Evrimsel bir bakış açısı, türlerin birbirlerine yardım etme ve birbirleriyle işbirliği içerisine girme davranışlarının, hayatta kalmayı ve dolayısıyla soyun devamını getirmeyi sağladığı için günümüzde halen var olduğunu söyler. Önceleri sadece yakın akrabalara (Akraba seçilimi; Hamilton, 1964) yönelik olduğu düşünülen bu tür davranışların, daha sonra akraba olmayanlara yönelik de ortaya çıkabildiği anlaşılmış ve "Bugün sana yarın bana" olacak şekilde bir karşılıklılık içerdiği ileri sürülmüştür (Karşılıklı diğerkâmlık; Trivers, 1971). Hatta bazı durumlarda anlık bir karşılık olmadığı halde özgeci ve işbirlikçi davranılabileceği, böylelikle itibar kazanarak gelecekteki olası yardımların güvenceye alınabileceği üzerinde de durulmuştur (Dolaylı diğerkâmlık; Nowak ve Sigmund, 2005).

Tüm bu yardım ve işbirliği özellikli davranışlar prososyal davranışlar olarak tanımlanmaktadır. Prososyal yönelim, yardım etme, başkası veya başkaları için kendinden feda etme, paylaşma, işbirlikçi olma gibi geniş bir yelpazeyi içermektedir (Batson ve Powell, 2003). Bu noktada, özgecilik ile işbirliği davranışlarının zaman zaman birbirine karışarak ${ }^{1}$, zaman zaman birbirinin üst-alt başlı̆̆ı olarak $^{2}$; zaman zaman da birbirinden ayrılarak ele alındığı görülebilmektedir. Özgeci davranış, kendinden verme pahasına bir başkasının yararını gözetmek ve bu yönde davranmaktır (Epistemolojik bir inceleme için Yeşilkaya, 2018). İşbirliği ise iki veya daha fazla kişinin ortak bir amaç uğruna bir araya gelmeleri ve bu uğurda çaba sarf etmeleri olarak tanımlanabilir. Türkçe'de de özgecilik ve işbirliği kelimelerinin tanımlamalarının bu şekillerde olduğu görülebilir (Türk Dil Kurumu, www.tdk.gov.tr).

Prososyal davranışlar olarak aynı çatı altında ele alınan, hatta kimi zaman iç içe geçmiş şekilde incelenen yapılar olan özgecilik ve işbirliğinin birbiriyle doğru orantılı oldukları düşünülebilir. Ancak hem tanımları hem de ölçümleri gereği bu iki eğilimi ayırmak ve bu yönde çalışmak gerekebilmektedir.

İşbirliğini özgecilikten ayırarak tek başına ele alan alanyazında genel olarak bu kavram rekabetçiliğin karşısında bir eğilim olarak karşımıza çıkmaktadır. Kültürel Antropolog Margaret Mead (1976), işbirliğini "Aynı sonuç için birlikte çalışma eylemi” olarak tanımlarken; rekabeti birlikte olmama eğilimi olarak "Diğerinin elde etmek istediği şeyi, onunla aynı anda bireyin de elde etmeye çabalaması eylemi" olarak tanımlamıştır (akt. Chen, Xie ve Chang 2011). Bazı yaklaşımlara göre, işbirliği ve rekabet birbirinin zıttı olarak konumlandırılmaktadır. Örneğin Deutsch (1949a; 1949b; 2006), sosyal durumlarda kişilerin amaçlarının birbiriyle olan bağlantısı üzerinde durmaktadır. Pozitif bağlantıda (işsirliği), kişinin hedefe ulaşmasının miktarı ve olasılı̆̆ diğer kişinin hedefe ulaşmadaki miktar ve olasılığı ile doğru orantılıdır. Bir başka deyişle kişinin amacına ulaşması diğer kişinin de amacına ulaşmasıyla doğru orantılıdır ve ikisinin birlikte bu amaca ulaşması daha kolaydır. Negatif bağlantıda ise (rekabet) kişinin hedefe ulaşmasının miktarı ve olasılığı diğer kişinin hedefe ulaşmadaki miktar ve olasılığı ile ters orantılıdır. Burada kişinin istenen amaca ulaşması, diğerinin ulaşamamasını gerektirmektedir. Pozitif bağlantı yani işbirliği, kişilerin birbirlerine olumlu duygular beslemesini; bir araya geldikleri için ödüllendirilmelerini; ortak kaynak paylaşımını; zorlukları birlikte aşmayı ve çoğunlukla aynı sosyal grupların üyesi olmayı getirir.

Deutsch (2006), kazan-kazan (win-win) bir işbirliğinin birçok sosyal çevrede ve durumda daha işlevsel olduğunu; benzer yönelimli insanların bulunduğu gruplara dâhil olmayı ve bu insanlarla bağlantıda kalmayı kolaylaştırdığını ileri sürmüştür. İşbirliğinde bulunmak; etkili iletişim sergilemeyi, tartışmalarda daha arkadaşça ve yardımsever bir tutumda olmayı, amaca yönelik daha etkin çabalayabilmeyi, diğerlerinin fikirlerini ve ihtiyaçlarını önemsemeyi ve çatışmaları ortak bir problem olarak görmeyi

\footnotetext{
${ }^{1}$ Örneğin; Henrich ve Muthukrishna (2020); işbirliği ile prososyal ve özgeci davranışları ayrıştırmadan incelemişlerdir.

${ }^{2}$ Örneğin Sachs, Mueller, Wilcox ve Bull, (2004); özgeciliğin her bir türünü işbirliğine dâhil ederek, işbirliği üst başlığı altında sınıflarına ayırarak incelemişlerdir.
} 
içermektedir. Rekabet durumunda olmak ise; iletişimin kopuk ya da kötü amaçlı olmasını, yardımlaşmaktan uzak olup diğerinin niyetini kötü algılamayı ve olumsuz eleştiri ve çatışmaları beraberinde getirmektedir. Tüm bu sebeplerin varlığı ile birlikte işbirliği ve rekabet eğilimi, birbiriyle zit kutuplarda yer almaktadır. Johnson ve Johnson'ın (1989; 2003) bu alanda yaptığı çeşitli çalışmalara göre, işbirliği grubun üreticiliğini arttırmakta, kişiler arası ilişkileri olumlu yönde etkilemekte, psikolojik iyilik halini ve benlik saygısını yükseltmektedir. Çatışmalar daha yapıcı şekilde çözülmektedir. Rekabetçilikte ise bu durumların tersi gözlenmektedir (akt. Deutsch, 2006).

Alanyazında işbirliğini ölçmeyi amaçlayan ölçeklerin kavramsallaştırma ile ilgili problemlerin etkisiyle sıklıkla özgecilik veya yardımlaşmayı da içeren ölçekler olduğu gözlenmiştir. Örneğin Cloninger, Przybeck, Svrakic ve Wetzel'in Mizaç ve Karakter Envanteri'nde (Temperament and Character Inventory; 1994; akt. Köse ve ark., 2004), işbirliği alt boyutu maddelerinin sosyal onaylama, empati duyma, yardımseverlik, acıma ve erdemlilik-vicdanlılık üzerine olduğu görülmektedir (Arkar ve arkadaşları, 2005; Köse ve arkadaşları 2004). İşbirliğine yönelik yurtiçi alanyazın incelendiğinde, işbirliği konusunu; örneğin okul-aile arasındaki (Alisinanoğlu, Bay ve Şimşek, 2014; Atabey ve Tezel Şahin, 2011); terapist-danışan arasındaki (Öztan, 1995); veya hemşire-hemşire arasındaki (Çelik Durmuş ve Yıldırım, 2016) gibi, bazı alanlara özelleşmiş şekilde incelemeye çalışan ölçekler olduğu gözlenmiştir. Dolayısıyla, hem yurtiçi hem de yurtdışı alanyazında işbirliğini benzeri kavramlardan ayıran ve işbirliğini genel-geçer bir boyut (domain-general trait) olarak ölçen araçların varlığına ihtiyaç olduğu görülmektedir. İşbirliği ve Rekabetçilik Ölçeği (Xie, Yu, Chen ve Chen, 2006) bu amaçla geliştirilmiş bir ölçüm aracı olarak ortaya çıkmaktadır.

Bu çalışmanın amacı kültüre özgü geçerli ve güvenilir bir işbirliği ölçümü elde etmektir. Ayrıca, geliştirilen ölçümün işbirliğini prososyal davranışlar gibi benzerlerinden ayırarak ölçebilmesi hedeflenmiştir. $\mathrm{Bu}$ amaçlar doğrultusunda, bu çalışmada İşbirliği ve Rekabetçilik Ölçeği'nden faydalanılarak işbirliğine yönelik bir ölçüm aracının geliştirilmesi hedeflenmiştir.

\section{İşbirlikçilik ve Rekabetçilik Ölçeği (İRÖ)}

Xie, Yu, Chen ve Chen (2006) tarafindan geliştirilen ölçeğin ön çalışmalarında, Mead'in (1976) işbirliği ve rekabet tanımları odak olarak alınmıştır. Buna göre işbirliği eğilimi yüksek bireyler diğerleriyle birlikte olmaya, onların bakış açılarını dikkate almaya ve birlikte çalışmaktan keyif almaya yönelik işbirlikçi tutumlar göstermektedirler. Rekabetçi olanlar ise diğerlerinden daha iyi olmaya çabalamaya ve hataları tolere edememeye meyilli olmaktadırlar. Buradan kaynak alınarak geliştirme çalışmalarına başlanan ölçeğin maddelerini oluşturmak için derinlemesine görüşmeler yapılmış ve daha eski benzer bazı ölçeklerin maddelerinden faydalanılmıştır. Açımlayıcı ve doğrulayıcı analizlerde işbirliği ve rekabet olmak üzere iki ayrı boyutta toplandığı ortaya çıkan maddeler neticede 23 madde ile son halini almıştır.

13 maddeden oluşan İşbirlikçilik Ölçeği; inançlar (4 madde; örn. "Üzerinde çalışılan işte başarı sağlayabilmek için grup üyeleri işbirliği içerisinde olmalıdır."), duygular (4 madde; örn. "Ortak başarı sağlamak için bir grup olarak çalışmak bana keyif verir.") ve davranışlar (5 madde; "İş üzerinde çalışırken, diğer grup üyelerinin fikirleri ve istekleri en az benimkiler kadar önemlidir.") olmak üzere üç alt boyuttan oluşmaktadır. 10 maddeden oluşan Rekabetçilik Ölçeği ise benzer şekilde; inançlar (3 madde; örn. "Rekabeti severim çünkü bu elimden gelenin en iyisini göstermek için bir fursattır."), duygular (4 madde; örn. " Ekip üyelerinden biriyle tartışırken altta kalmaya katlanamam.") ve davranışlar (3 madde; "Grup olarak çalışıyor bile olsak, yine de diğerlerinden daha iyi performans göstermek isterim.") olmak üzere üç alt boyuttan oluşmaktadır (Chen, Xie ve Chang, 2011; Xie ve arkadaşları, 2006). Chen ve arkadaşlarının çalışmasında (2011) ise, İşbirlikçilik Ölçeği ile örgütsel vatandaşlık davranışlarının pozitif korelasyon sergilediği, Rekabetçilik Ölçeğinin ise bu ilişkiye katılmadığı görülmüştür ve böylece ölçeklerin kriter geçerlilikleri sağlanmıştır.

Ölçeğin yapı ve kriter geçerliğinin yürütüldüğü bir diğer çalışmada, doğrulayıcı faktör analizi sonucunda iki boyutlu yapı desteklenmiştir ( $\mathrm{Lu}$, Au, Jiang, Xie ve Yam, 2012). Ayrıca İşbirlikçilik boyutu Schwartz'ın (Schwartz, ve Bilsky, 1990) evrenselcilik ve iyilik-cömertlik değerleri ile ilişkili çıkarken; rekabetçilik boyutu daha çok güç ve başarı değerlerine ile ilişkili bulunmuştur. Bu sonuçlara göre işbirliği ve rekabetin farklı psikolojik yapılarla alakalı olduğu düşünülmüştür. Son olarak "Public Goods" ekonomik oyununda, işbirlikçilerin oyunda daha çok katkı gösterdikleri ve daha çok fedakâr 
davrandıkları görülmüştür. Bu da işbirlikçilik puanları yüksek kişilerin daha özgeci oldukları anlamına gelmektedir.

\section{İşbirliği Ölçeği (İÖ)}

İşbirliği yönelimini ve tutumunu çalışabilmek adına, yurtiçi alanyazındaki eksikliği de göz önüne alarak, İRÖ üzerinde bir uyarlama çalışması yapılması planlanmıştır. Öncelikle İRÖ maddeleri iki dil uzmanı ve bir de alan profesörü yardımıyla Türkçeye çevrilmiş ve maddeler incelenmiştir. Bu aşamada, ölçeklerin inanç, duygu ve davranış alt boyutlarının maddelerinin Türkçedeki tam anlamını karşılamadığı; dahası bazı maddelerin çeviride birbirine çok yakın anlamda olduğu dikkat çekmiştir ${ }^{3}$. Dolayısıyla benzer anlamlı maddelerden en temsil edici olanı seçilmiş, dile daha uygun olacak şekilde adapte edilmiştir. Öte yandan işbirliği kavramını işbirliği-rekabet karşıtlığından çok, işbirliği eğilimi sergilemedeki düzeyler olarak incelenmesi amaçlandığı için; Rekabetçilik ölçeğinden seçilen bazı maddeler de ters madde olarak alınıp tek bir ölçeğe toplanmıştır. Neticede İşbirlikçilik ölçeği maddelerinden esinlenerek 9 madde oluşturulmuş (madde 1, 2, 4, 5, 7, 8, 9, 13 ve 14); Rekabetçilik Ölçeğinin maddelerinden esinlenerek 6 madde oluşturulmuş (madde 3, 6, 10,11, 12 ve 16); son olarak da Türkiye kültüründe sıkça kullanılan "Bir elin nesi var, iki elin sesi var" atasözü bir madde olarak (madde 15) eklenmiştir. Toplamda 16 maddeden oluşan İşbirliği Ölçeği, geçerlik ve güvenirlik analizleri kapsamında çalışılmıştır. ${ }^{4}$

\section{YÖNTEM}

\section{Örneklem}

Araştırmanın örneklemini, 210 katılımcı arasından uygulamayı eksiksiz tamamlayan 171 üniversite öğrencisi oluşturmuştur ve veriler İstanbul Üniversitesi'nden bilgilendirilmiş onam eşliğinde toplanmıştır. 142 kadın ve 29 erkek katılımcıdan oluşan örneklemin yaş ortalaması 22'dir (Ss.=3.2) ve katılımcıların çoğu orta gelir sahibi (\%59) olup yaşamlarının büyük kısmını büyükşehirlerde (\%61) geçirdiklerini belirtmişlerdir (bkz. Tablo 1).

Tablo 1. Demografik Bilgiler

\begin{tabular}{lc}
\hline Sayı $(N)$ & 171 \\
Cinsiyet & \\
Kadın & $142(\% 83)$ \\
Erkek & $29(\% 17)$ \\
Yaş [ortalama (SS)] & $21.96(3.22)$ \\
Sosyoekonomik Düzey & \\
$\quad$ Çok iyi & $6(\% 3.5)$ \\
İyi & $59(\% 34.5)$ \\
Orta & $100(\% 58.5)$ \\
Düşük & $6(\% 3.5)$ \\
Çok düsüük & - \\
Yaşanılan yer & \\
Büyükşehir & $105(\% 61.4)$ \\
Şehir & $30(\% 17.5)$ \\
İlçe/Belde & $35(\% 20.5)$ \\
Köy & $1(\% 1.6)$ \\
\hline
\end{tabular}

\footnotetext{
${ }^{3}$ Örneğin İşbirlikçilik Ölçeğinin duygular alt boyutundaki iki madde şu şekildedir: "Ekip üyeleriyle çalışmak beni mutlu eder (Working with team members makes me happy) ve "İş yerinde, ekip üyeleriyle iş birliği yapmayı severim (At work, I like collaborating with team members)". Anlaşılabileceği üzere bu iki madde anlam açısından birbirine oldukça yakındır ve 13 maddelik bir ölçeğin içerisinde birlikte bulunmaları gerekli görülmemektedir. Bu durumun önce Çinceden İngilizceye ve İngilizceden Türkçeye çevrilmiş olan maddelerin çeşitli anlam kayıpları yaşamış olabileceklerinden kaynaklandığı düşünülebilir. Ancak elde kalan maddelerin ölçek için yeterli olduğu ve ölçeğin anlam değerini düşürmediği kanısına varılmıştır.

4 İRÖ'nün yazarları söz konusu adaptasyon çalışmasındaki işlemlerle ilgili bilgilendirilmiş ve süreçle ilgili onayları alınmıştır.
} 


\section{Veri Toplama Araçları}

İşbirliği Ölçeği: Xie, Yu, Chen ve Chen'in (2006) İşbirlikçilik ve Rekabetçilik Ölçeği'nden yola çıkarak araştırmacılar tarafindan oluşturulan ölçek 16 maddeden oluşmaktadır. 9 madde işbirlikçi tutumları (örn. "Üzerinde çalışılan işte başarı sağlayabilmek için grup üyeleri işbirliği içerisinde olmalıdır."); 6 madde ters madde olacak şekilde rekabetçi tutumları (örn. "Grup çalışmasıyla bir iş yürütmektense tek başıma olmayı tercih ederim.") ve 1 madde de kültürel açıdan anlamlı bulunan bir atasözünü ("Bir elin nesi var, iki elin sesi var" atasözü çok doğru bir noktaya değinmektedir.") içermektedir. Maddeler 5'li likert tipi ölçekle değerlendirilmektedir (1=Kesinlikle katılmıyorum; 5=Kesinlikle katılıyorum). Ölçeklerin orijinallerinin güvenirlikleri İşbirliği Ölçeği için .85 - .87; Rekabetçilik Ölçeği için .71 - .79 arasında ranj göstermektedir. Türkçe uyarlama çalışması, araştırma dâhilinde yürütülmektedir. Bu çalışma kapsamında oluşturulan ölçümün son halinin iç tutarlılık katsayısı .85 olarak bulunmuştur.

Prososyal Niyet Anketi: Kişilerin özgeci yönelimlerini ve niyetlerini ölçmek için Jordan, Mullen ve Murnighan (2011) tarafindan geliştirilen ölçek, 3 çeldirici madde (örn. "Beklediğiniz bir filmin sinemaya geldiğini varsayın. Önemli bir sinav öncesi bu filme gitme ihtimaliniz nedir?") ve 3 ana madde (örn. "Üniversitenizde babası iflas eden bir öğrencinin olduğunu varsayın. Bu öğrencinin üniversite masraflarına katkıda bulunmak için bağış yapma ihtimaliniz nedir?") ile birlikte toplamda 6 ifadeden oluşmaktadır. Katılımcıların okudukları cümlelere göre diğer haftalar içerisinde bahsi geçen faaliyette bulunma olasılıkları açısından kendilerini 7'li likert tipi ölçekte (1=Hiç olası değil; 7=Çok olası) değerlendirmeleri istenmektedir. Yapılan analizler prososyal niyeti ölçen 3 ana maddenin tek bir faktörde toplandığını göstermiştir. Ölçeğin Türkçe uyarlaması Yılmaz ve Bahçekapılı (2016) tarafından gerçekleştirilmiş ve araştırmalarında sorunsuz şekilde kullanılmıştır. Ölçeğin bu çalışmadaki iç tutarlılık katsayısı yeterli düzeydedir (Cronbach's alpha $=.36$ ).

Alternatif Tutsak İkilemi Oyunu: İşbirliği eğilimini başka bir ölçüm ile değerlendirmek açısından, tutsak ikilemi (Prisoner's Dilemma; Flood ve Dreschner, 1950; Tucker, 1951; akt. Kuhn, 2019) ekonomik oyunundan yola çıkarak alternatif bir hikâye oluşturulmuştur ${ }^{5}$. Derslerine eklenecek ekstra puanlara göre uyarlanan hikâyede, öğrencilerden ortadaki bir miktar puanı diğer bir öğrenciyle bölüşmek (işbirliği) veya hepsini kendilerine almak üzere tercihler yapmaları istenmiştir. Öğrencilere hipotetik olarak verilen hikâyeye göre; ortada 10 puan bulunmaktadır ve bu puanla ilgili verecekleri karar (bölüşmek veya almak) seçkisiz olarak kim olduğu bilinmeyen bir başka öğrencinin kararıyla eşleştirilecektir. Bu eşleşmeye göre ise öğrencinin ekstra kaç puan alacağı belirlenecektir:

- $\quad$ İki öğrenci de bölüşmeyi seçtiyse her biri 5'er puan alacak;

- $\quad$ Biri bölüşmeyi biri almayı seçtiyse, bölüşmeyi seçen öğrenci hiç puan alamazken almayı seçen öğrenci 10 puanın hepsini alacak;

- $\quad$ İki öğrenci de almayı seçtiyse ise iki taraf da hiç puan alamayacaktır (bkz. Tablo 2).

Tablo 2. Alternatif Tutsak İkilemi Oyununda Puanların Dă̆glımı

1. Oyuncu

\begin{tabular}{|c|c|c|c|}
\cline { 3 - 4 } \multicolumn{1}{c|}{} & Bölüş & Al \\
\cline { 2 - 4 } & Bölüş & $0-0$ & $0-10$ \\
\hline Al & $10-0$ & $0-0$ \\
\hline
\end{tabular}

Bu bilgilere dayanarak seçimlerini gerçekleştirecek öğrencilere oyun art arda 3 kez oynatılmakta ve her seferinde seçkisiz şekilde başka bir bilinmeyen öğrencinin tercihleriyle eşleştirilecekleri bilgisi verilmektedir. Sonuç olarak ölçekten en düşük 0 ve en yüksek 3 puan elde edilmekte; yüksek puan

\footnotetext{
${ }^{5}$ Alternatif Tutsak İkilemi hikâyesi, Prof. Dr. Sevim Cesur danışmanlığında sorumlu yazar tarafından yürütülmekte olan doktora tezi kapsamında oluşturulmuştur.
} 
yüksek işbirliği eğilimini temsil etmektedir. Yapılan ön çalışmalar ve öğrencilerden alınan geri bildirimler, Alternatif Tutsak İkilemi hikâyesinin öğrenciler tarafından sorunsuz şekilde anlaşıldığını göstermiştir. Ölçeğin iç tutarlılık katsayısı yeterli düzeydedir (Cronbach's alpha = .76).

İşbirliği Olarak Ahlak Ölçeği: İnsan ahlakının temellerini evrimsel süreçteki işbirliği davranış örüntüleri ile açıklayan İşbirliği Olarak Ahlak Kuramı (Curry, 2016) çerçevesinde, Curry, Chesters ve Van Lissa (2019) tarafından geliştirilmiş bir ölçektir. Kuramın 7 boyutunu (Aile, Grup, Karşılıklılık, Kahramanlık, İtaat, Adalet ve Mülkiyet; her boyut için 6 madde olacak şekilde) değerlendirmeyi amaçlayan ölçek; 42 maddeden ve 2 bölümden oluşmaktadır. İlk bölümde kişilerin bir olayın doğruluğunu veya yanlışlığını değerlendirirken verilen ifadelerin (örn. "Birisinin güvenilebilecek biri olduğunu kanttlayıp kanıtlamadığı") ne kadar etkili olduğuna karar vermeleri beklenmektedir. İkinci bölümde ise katılımcıların bazı ahlaki yargıları değerlendirmeleri istenmektedir (örn. "Bireylerin gruplarında aktif bir role sahip olmaları önemlidir"). Ölçek, $0-100$ arası bir puanlama ile değerlendirilmektedir ( $0=$ Kesinlikle katılmıyorum; 100=Kesinlikle katılıyorum) ve Türkçe uyarlaması Yılmaz, Harma ve Doğruyol (2020) tarafindan gerçekleştirilmiştir. Bu çalışmada, alt boyutların iç tutarlılık katsayıları sırasıyla .78, .79, .67, $.82, .86, .55$ ve .68 olarak bulunmuştur.

\section{Verilerin Analizi}

Betimleyici istatistikler ve geçerlik analizleri IBM SPSS 26.0, doğrulayıcı faktör analizleri ise Jamovi paket programı kullanılarak gerçekleştirilmiştir. Analizlerde öncelikle bir dizi doğrulayıcı faktör analizi yürütülerek ölçeğin yapı geçerliği incelenmiştir. Geçerli bir faktör yapısına ulaşıldıktan sonra işbirliği ölçeğinin uyum geçerliğini incelemek üzere katılımcıların İşbirliği Ölçeği skorlarının Alternatif Tutsak İkilemi oyunundaki davranışsal stratejiler bağlamında farklılaşıp farklılaşmadığı bağımsız örneklem ttesi ile test edilmiştir. Son olarak, yine aynı amaçla işbirliği ölçeği değerlendirmeleri ile iş birliği olarak ahlak ölçeğinin alt boyutları arasındaki ilişkiler korelasyon analizleri ile incelenmiştir.

Doğrulayıcı faktör analizlerinde girdi (input) olarak ham veri seti kullanılmıştır. Modeller maksimum olabilirlik kestirim yöntemi (maximum likelihood estimation) ile yordanmıştır. Model uyumu için normal teori ağırlıklı minimum kareler $\chi^{2}$ değerlendirilmiştir. Ayrıca, Hu ve Bentler'in (1999) iki indeks stratejisine uygun şekilde RMSEA, CFI ve TLI değerleri model uyumunun incelenmesi amaciyla kullanılmıştır. Bu ek indeksler hem $\chi^{2}$ nin, hem de $\chi^{2} / \mathrm{df}$ oranının katılımcı sayısından fazlasıyla etkilenmesi ve güvenilir olmaması nedeniyle tercih edilmiştir (Barrett, 2007). RMSEA için .08'in altındaki değerler, CFI ve TLI için .90 'nın üzerindeki değerler modelin veriye uyum gösterdiğine işaret etmektedir.

\section{Araştırmada Etik}

Araştırma etiği kapsamında çalışmanın yapılabilmesi için İstanbul Üniversitesi Sosyal ve Beşeri Bilimler Araştırmaları Etik Kurulu Başkanlığı 26/09/2019-208578 tarih ve sayısı ile gerekli onayı vermiştir.

\section{BULGULAR}

\section{Açımlayıcı Faktör Analizi}

İşbirliği ölçeğinin 16 maddesine açımlayıcı faktör analizi yapılmıştır. Analiz sonuçları özdeğeri birin üzerinde olan dört faktör olduğunu göstermiştir. Ancak birinci faktörün özdeğerinin diğer faktör özdeğerlerinden yüksek olması tek bir faktörün varlığına işaret etmektedir $(4.32,1.75,1.56,1.34)$ Kırılma eğrisi (Figür 1) ise tek bir faktörün olduğuna işaret etmiştir. İlgili istatistikler ve faktör yapılarının incelenmesi sonucu tek faktörlü yapının uygun olduğuna karar verilmiştir. 
Figür 1. Açımlayıcı Faktör Analizi Kırılma Ĕgrisi

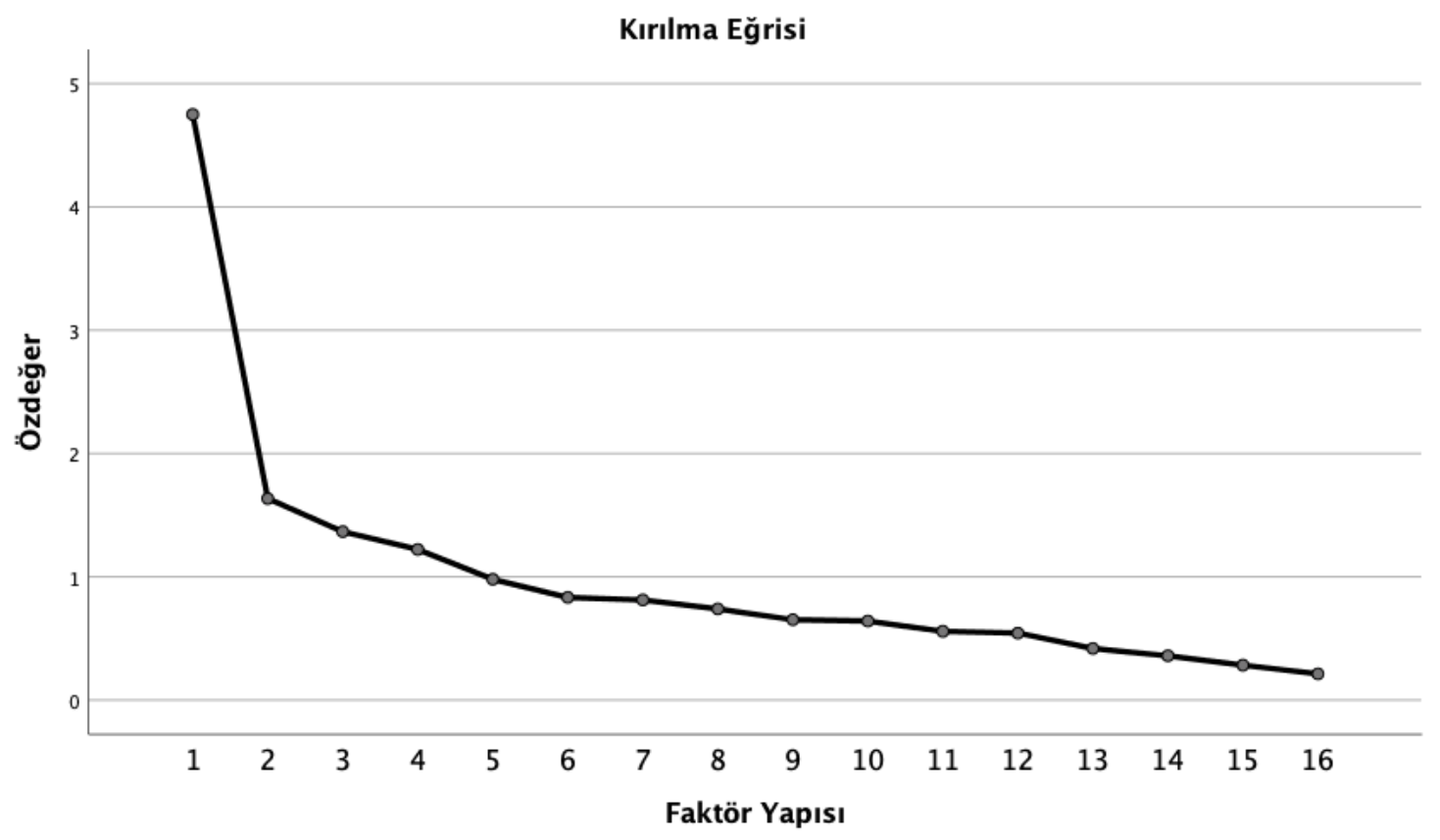

Keiser-Meyer-Olkin (KMO; .81) istatistiği maddelerin faktörleştirilebileceğini göstermiştir. Bu değerin .80 ve üzeri olması maddeler arası ilişkilerin faktör yapıları oluşturmak için yeterli olduğuna işaret etmektedir (Tabachnick ve Fidell, 2007). Tek faktörlü yapının özdeğeri 4.75 ve açıkladığı varyans \%29.69 olarak bulunmuştur. Maddelerin 11'i işbirliği faktörüne anlamlı olarak yüklenmiştir. $\mathrm{Bu}$ maddelerin faktör yükleri .34 ile .82 arasında değişmektedir (Tablo 3). Ölçeği 11 maddeden oluşan son formunun iç tutarlılığının yüksek olduğu bulunmuştur $(\alpha=.85)$.

Tablo 3. İşbirliği Ölçeği Maddeleri Üzerinde Açımlayıcı Faktör Analizi Sonuçları

7. Ortak başarı sağlamak için bir grup olarak çalışmak bana keyif verir.

İşbirliği

15. "Bir elin nesi var, iki elin sesi var" atasözü çok doğru bir noktaya değinmektedir.

5. İş üzerinde tek başıma çalışmaktansa başkalarıyla işbirliği içerisinde çalışmayı tercih ederim.

8. İnsanlarla işbirliği kurarak hem kendimizin hem de onların iyiliği için çalışmak en iyisidir.

4. Üzerinde çalışılan işin iyi sonuçlanacağını öne sürerken birlikte çalışılan grup üyelerinin katkılarına güvenirim.

11. Grup çalışmasıyla bir iş yürütmektense tek başıma olmayı tercih ederim.

13. Bir iş üzerinde çalışırken diğerleriyle iyi bir ortaklık ve işbirliği kurmak, rekabete girip yalnız çalışanlardan daha başarılı olmayı sağlar.

1. Üzerinde çalışılan işte başarı sağlayabilmek için grup üyeleri işbirliği içerisinde olmalıdır.

9. Grup içinde kimin daha iyi çalıştı̆̆ 1 veya daha çok iş yaptığına odaklanmak yerine, birlik ve beraberliği yüreklendirmek en mantıklısıdır.

14. İş üzerinde çalışırken, diğer grup üyelerinin fikirleri ve istekleri en az benimkiler kadar önemlidir.

2. Grup içinde rekabete girişmek yerine işbirliği kurmak, üzerinde çalışılan işteki performansi arttırır.

10. Aynı gruptaki diğer üyelerin kişiden daha iyi performans sergilemeleri ve takdir edilmeleri sinir bozucudur.

16. İçerisinde bulunduğum grubun çalıştığı işte başarısız olması, herkesin eşit hatası olsa bile en çok beni üzer.

3. Rekabet içeren bir ortamda yumuşak meydan okumalar eşliğinde çalışmak, bir yarışmaya katılmak gibi olacağından eğlencelidir. 
12. Başkalarıyla rekabet içerisinde olmak insanın kendi potansiyelini gerçekleştirmesi açısından önemlidir.

6. Ortak bir iş üzerinde grupça çalışırken kişi elinden gelenin en iyisini yapmalı ve diğerlerinden her zaman daha başarılı olmalıdır.

\begin{tabular}{lc}
\hline Özdeğer & 4.75 \\
Açılanan varyans & $\% 29.69$ \\
Güvenirlik & .85 \\
\hline
\end{tabular}

\section{Doğrulayıcı Faktör Analizleri}

İlk modelde bütün maddeler işbirliği olarak tanımlanan tek bir gizil değişkeni ölçecek şekilde tanımlanmıştır. Çalışmada yürütülen bütün modellerin sonuçları Tablo 4'te verilmiștir. Buna göre, 16 maddenin kullanıldığ ilk modelin uyum indeksleri yetersizdir $\left(\chi^{2}(104)=250, \mathrm{CFI}=.798\right.$, TLI $=.767$, RMSEA = .091, (90\% CI [.076-.105)). Model incelendiğinde, beş maddenin işbirliği gizil değişkenine anlamlı olarak yüklenmediği gözlenmiştir. İkinci modelde bu maddeler çıkarılarak doğrulayıcı faktör analizi tekrarlanmıştır. İkinci modelin uyum indekslerinin ilk modele kıyasla gelişmekle birlikte yetersiz olduğu gözlenmiştir $(\chi 2(44)=138, \mathrm{CFI}=.859, \mathrm{TLI}=.824, \mathrm{RMSEA}=.112,(90 \%$ CI [.091-.133])). Bu modelde, bütün maddeler anlamlı olarak yüklenmiştir. Hata indeksleri incelendiğinde, bazı maddeler arasında yüksek ilişki olduğu gözlenmiştir. Üçüncü modelde, model uyum indekslerini geliştirmek amacıyla madde 5 ("İş üzerinde tek başıma çalışmaktansa başkalarıyla işbirliği içerisinde çalışmayı tercih ederim") ile madde 11 ("Grup çalışmasıyla bir iş yürütmektense tek başıma olmayı tercih ederim") ve madde 5 ile madde 15 ("Bir elin nesi var, iki elin sesi var atasözü çok doğru bir noktaya değinmektedir") arasındaki hatalar ilişkilendirilmiştir. Yeni model uyum indeksleri, verinin modele yeterli düzeyde uyum gösterdiğine işaret etmektedir $(\chi 2(42)=90.2, \mathrm{CFI}=.928, \mathrm{TLI}=.906, \mathrm{RMSEA}=$ .081, (90\% CI [.059-.105])). Son model için standart faktör yükleri Figür 2'de gösterilmiştir.

Tablo 4. Doğrulayıcı Faktör Analizlerinin Uyum İdeksleri

\begin{tabular}{lllll}
\hline Model & $\chi 2(\mathrm{df})$ & RMSEA(90\% CI) & CFI & TLI \\
\hline Tam ölçek & $250(104)$ & $.091(.076-.105)$ & .798 & .767 \\
\hline Kısaltılmış ölçek & $138(44)$ & $.112(.091-.133)$ & .859 & .824 \\
\hline $\begin{array}{l}\text { Kisaltılmıs ölçek } \\
\text { (Hata varyansları eklenmiş) }\end{array}$ & $90.2(42)$ & $.081(.059-.105)$ & .928 & .906 \\
\hline
\end{tabular}


Figür 2. İşbirliği Ölçeğinin Faktör Yükleri

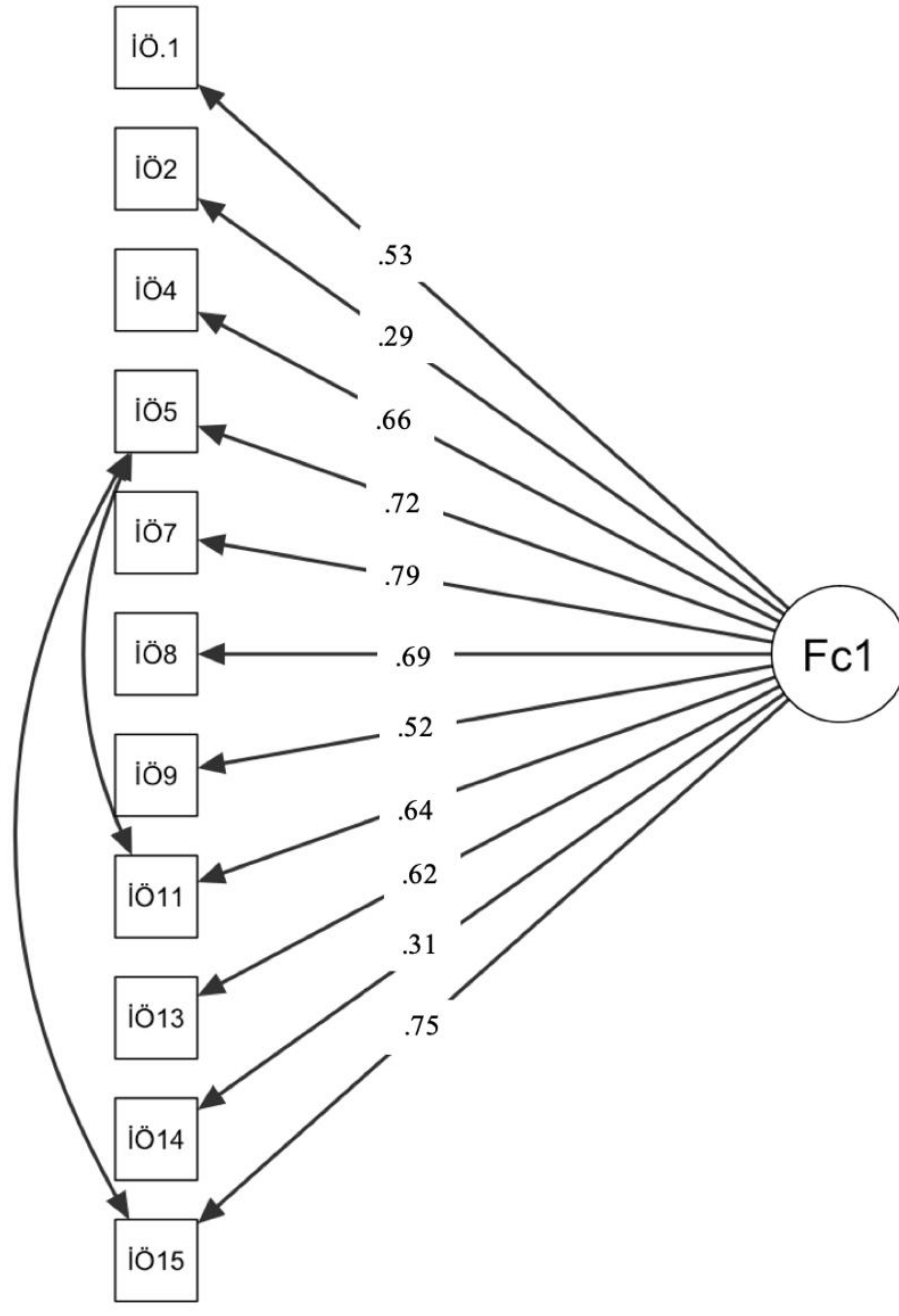

\section{Benzer Ölçekler Geçerliği}

İşbirliği ölçeğinin final formunun geçerliğini test etmek amacıyla katılımcıların Alternatif Tutsak İkilemi oyunundaki kararlarının işbirliği ölçeği skorları üzerinde farklılaşıp farklılaşmadığına bakılmıştır. Oyunda katılımcılar işbirliği (bölüş) ya da rekabet (al) olmak üzere iki karar vermişlerdir. Bağımsız örneklem t-testi sonuçları, işbirlikçi davranış stratejisini benimseyen katılımcıların $($ Ort. $=4.24, S S=$ $.55)$, rekabetçi stratejiyi benimseyen katılımcılardan $($ Ort. $=3.96, S S=.67)$ anlamlı olarak daha yüksek düzeylerde işbirliği beyan ettiklerini göstermektedir $(t(169)=2.826, p=.005)$.

Ek olarak, katılımcıların işbirliği olarak ahlak ölçeğinin alt boyutlarından aldıkları skorlar ile işbirliği ölçeği değerlendirmeleri arasındaki ilişkiler incelenmiştir. Sonuçlara göre, işbirliği ölçeği, aile $(r=.27, p$ $<.001)$, grup $(r=.31, p<.001)$, karş11kl11ık $(r=.21, p<.01)$, kahramanlık $(r=.23, p<.01)$ ve itaat $(r=$ $.37, p<.001)$ ile olumlu yönde anlamlı ilişkiler gösterirken adalet ve mülkiyet ile işbirliği skorları arasındaki ilişkiler anlamsız olarak bulunmuştur. Son olarak, işbirliği ölçeğinin yüksek düzeyleri prososyal niyet anketinin yüksek düzeyleri ile ilişkili bulunmuştur $(r=.26, p<.001)$.

\section{TARTIŞMA}

İşbirliğinin kavramsallaştırılması ve ölçümü, ahlak psikolojisi ve evrimsel psikoloji gibi alanların üzerinde durduğu araştırma konularından birisi olarak ortaya çıkmaktadır (Curry ve ark., 2019; Sachs ve ark., 2004; West ve ark., 2007). Bu çalışmada, işbirliğini tutum düzeyinde ölçebilecek bir ölçüm aracının alanyazına kazandırılması hedeflenmiştir. Bu hedef doğrultusunda, Xie, Yu, Chen ve Chen (2006) tarafından geliştirilen İşbirlikçilik ve Rekabetçilik Ölçeği kapsamındaki İşbirlikçilik Ölçeği'nin kültürel 
adaptasyonu yapılmıştır. Ek olarak, Rekabetçilik Ölçeği'nin bazı maddeleri ters kodlanan maddeler olarak ölçüme eklenerek işbirliği ve rekabetçilik kavramlarının ilişkileri incelenmiştir.

Doğrulayıcı faktör analizlerinin sonuçlarına göre ölçeğin elde edilen son halinin kendi içinde tutarlı ve işbirliği eğilimini temsil edici maddelerden oluştuğu ve Türk kültüründe kullanılmaya uygun olduğu sonucuna varılmıştır. Ölçeğin final formu İşbirlikçilik Ölçeği'nin dokuz maddesi, Rekabetçilik Ölçeği'nden ters kodlanan bir madde ve kültüre özgü olarak geliştirilen bir maddeden oluşmuştur. Toplam 11 maddeden oluşan ölçeğin yeterli düzeyde uyum indekslerinin olması, yapı geçerliği olduğuna işaret etmektedir.

Ölçekten atılan maddeler incelendiğinde, bu maddelerin Rekabetçilik Ölçeği'nden alınıp ters madde olarak ölçeğe eklenen 6 maddenin 5'i olduğu görülmektedir. Dolayısıyla bunun, Xie ve arkadaşları'nın (2006) işbirliği ve rekabet kavramlarını iki ayrı boyut olarak inceleme yaklaşımlarıyla tutarlı olduğu düşünülmüştür. Bir başka deyişle, işbirliği ve rekabetçilik kavramlarının bir boyutun iki ucunda olan (unidimensional) kavramlar olmayabileceği, birbirinden bağımsız iki ayrı kavram oldukları sonucu desteklenmiştir.

Kavramsallaştırma ile ilgili tartışmada dikkat edilmesi gereken bir nokta, bu çalışmada kullanılan İşbirliği Ölçeği'nin işbirliğini davranış değil tutum düzeyinde ölçüyor olmasıdır. Sosyal psikolojide tutum ve davranışların birbirleri ile örtüşmeyebileceğini gösteren çalışmalar bulunmaktadır (Ajzen ve Fishbein, 2005; Glasman ve Albarracín, 2006; LaPiere, 1934). Mevcut çalışmada, İşbirliği Ölçeği’nin benzer ölçekler geçerliliği için davranışı farklı bir temelden ele alarak ikilemler üzerinden ölçen bir ekonomik oyun olan Alternatif Tutsak İkilemi kullanılmış ve ölçümlerin birbirleri ile olan ilişkileri incelenmiştir. Ek olarak, işbirliği ve özgeciliğin kavramsallaştırmaları üzerindeki tartışmalara ışık tutabilmek ve İşbirliği Ölçeği’nin geçerliğine ek katkı sağlamak üzere Prososyal Niyet Anketi de çalışmaya dâhil edilmiştir.

İşbirliği Ölçeği'nin Alternatif Tutsak İkilemi’nden alınan işbirliği puanlarıyla ve Prososyal Niyet Anketi ile belirlenen özgecilik değerleriyle olumlu ilişki göstermesi, başka bir deyişle kişilerin İşbirliği Ölçeği ile belirlenen işbirliği eğilimleri yükseldikçe ikilemdeki hipotetik olarak ölçülen işbirliği davranışları ve özgeci eğilimlerinin yükselmesi, ölçeğin işbirliği kavramını beklenen şekilde ölçtüğüne işaret etmektedir. İşbirliği ve özgecilik kavramlarının alanyazında birbiri ile iç içe kullanılabilmesinden (Henrich ve Muthukrishna, 2020) de anlaşllabileceği üzere bu eğilimlerin birlikte değişimlenmesi beklendiktir. Tanımları ve temel anlamları gereği ayrı ayrı ele alınıp ölçülmeye çalışıldıklarında da olumlu korelasyon içerisinde olmaları, birbirine yakın kavramlar olduklarını tekrar vurgulamaktadır. Ancak amaca yönelik olarak ayrı ayrı ölçülebilir olmaları değerli görülmektedir. Ek olarak, özgecilik ile işbirliğinin düşük ila orta düzeylerde ilişki göstermesi, bu kavramların ilişkili ancak birbirinden farklı kavramlar olduğuna işaret etmektedir. İleriki çalışmalarda, geçerli ve güvenilir ölçümler kullanılarak işbirliği ve özgeciliğin ilişkisi ile bu kavramların mekanizmalarının incelenmesi, ilgili alanyazına önemli katk1lar sunabilir.

Ayrıca, henüz yeni bir kuram olmasına karşın evrimsel işbirliği yaklaşımı açısından önemli görülen İşbirliği Olarak Ahlak Kuramı'nın ölçeğiyle olumlu yönde anlamlı bir ilişki gösteren İşbirliği Ölçeği, başka bir temelden işbirliği eğilimine atıf yapan bir yaklaşım ile de uyumlu bulunmuştur. İşbirliği Ölçeği, kişilerin işbirliği yapmasına neden olan yedi temel evrimsel motivasyondan beşi ile anlamlı ilişkiler göstermiştir. Gelecek çalışmalarda, bu ilişkilerin daha detaylı incelenmesi, hem işbirliğinin ölçümü için hem de altında yatan mekanizmaların anlaşılması açısından değerli olabilir.

Sonuç olarak adaptasyonu gerçekleştirilmiş olan İşbirliği Ölçeği'nin, kişilerin işbirliği eğilimlerini ve işbirliğine yönelik tutumlarını ölçmek adına geçerli ve güvenilir bir ölçek olduğuna görülmüştür. Son haliyle 11 maddeden oluşan ölçeğin bu yönüyle de kullanımının elverişli olduğu düşünülmektedir.

Çalışmanın yürütüldüğü örneklem büyüklüğü ve cinsiyet ile yaş dağılımı açısından araştırmanın sınırlı olabileceği göz önüne alınmalıdır. İlgili diğer çalışmaların daha temsil edici ve sayıca fazla katılımcı içeren örneklemlerde tekrar edilmesi önemli görülmektedir. Ayrıca, Prososyal Niyet Anketi'nde gözlenen tavan etkisi ve düşük iç tutarlılık katsayısı, özgecilik ile işbirliği arasındaki ilişkileri anlamayı zorlaştırmaktadır. Dahası, bulgular sadece işbirliği değil özgeci davranışın ölçümü için de geçerli ve güvenilir bir ölçüm aracı ihtiyacına işaret etmektedir. Dolayısıyla, bu çalışmadan elde edilen işbirliği ve 
özgecilik ölçümleri arasındaki ilişkilerin ileriki çalışmalarda tekrar incelenmesi önemli gözükmektedir. Ek olarak, İşbirliği Ölçümü'nün işbirliğinin davranışsal ölçümleri ile olan ilişkisi bu çalışmada sadece hipotetik düzeyde ele alınmıştır. Gelecek çalışmalarda, işbirliğinin davranışsal ölçümleri ile olan ilişkilerinin incelenmesi ölçeğin geçerliği açısından değerli olacaktır.

\section{Bilgilendirme / Acknowledgement:}

1- Araştırmacıların katkı oranı eşittir. Makalede ölçek ile ilgili çalışmalar ilk yazar tarafindan, analizler ise her iki yazar tarafından beraberce yapılmıştır. Bu yüzden makalede tez danışmanının adı -bilgisi dahilinde- yazılmamıştır.

2- Makale, sorumlu yazar Yağmur Gözde Yerlikaya’nın Prof. Dr. Sevim Cesur danışmanlığında İstanbul Üniversitesi Psikoloji bölümünde yürüttüğü “Ahlaki Temellerin Bazı Kültürel ve Bireysel Değişkenler Aracıllı̆ıyla İşbirliği Davranışına Etkisi”" başlıklı doktora tezinin bir bölümünden üretilmiştir.

3- Prof. Dr. Sevim Cesur'a katkı ve desteklerinden dolayı teşekkürlerimizi sunarız.

4- Makalenin yazarları arasında çıkar çatışması bulunmamaktadır.

5- Makalemizdeki veriler 2020 öncesi toplanmış olup çalışma doktora tezinden üretilmiştir ve söz konusu tezin tüm kapsamının etik kurul onayı bulunmaktadır. Araştırma etiği kapsamında çalışmanın yapılabilmesi için İstanbul Üniversitesi Sosyal ve Beşeri Bilimler Araştırmaları Etik Kurulu Başkanlı̆̆ı 26/09/2019-208578 tarih ve sayısı ile gerekli onayı vermiştir.

6- Bu makalede araştırma ve yayın etiğine uyulmuştur.

\section{KAYNAKÇA}

Ajzen, I. \& Fishbein, M. (2005). The influence of attitudes on behavior. D. Albarracín, B. T. Johnson ve M. P. Zanna (Ed.). The handbook of attitudes içinde. 173-221. UK: Lawrence Erlbaum Associates Publishers.

Alisinanoğlu, F., Bay, D. N. \& Şimşek, Ö. (2014). Okul öncesi eğitimde okul aile işbirliği ölçeği'nin geçerlik ve güvenirlik çalışması. Ahi Evran Üniversitesi Kırşehir Eğitim Fakültesi Dergisi, 15(1), $1-13$.

Arkar, H., Sorias, O., Tunca, Z., Şafak, C., Alkın, T., Binnur Akdede, B., Şahin, S., Akvardar, Y., Sarı, Ö., Özerdem A. \& Cimilli, C. (2005). Mizaç ve Karakter Envanteri'nin Türkçe formunun faktör yapısı, geçerlik ve güvenilirliği. Türk Psikiyatri Dergisi, 16(3), 190-204.

Atabey, D. \& Tezel Şahin, F. (2011). Aile öğretmen iletişim ve işbirliği ölçeği. Kastamonu Ĕ̆itim Dergisi, 19(3), 793-804.

Barrett, P. (2007). Structural equation modelling: Adjudging model fit. Personality and Individual Differences, 42(5), 815-824.

Batson, C. D. \& Powell, A. A. (2003). Altruism and prosocial behavior. T. Millon, M. J. Lerner ve I. B. Weiner, (Ed.). Handbook of psychology: volume 5 personality and social psychology içinde. 463485.UK: Wiley Online Library.

Chen, X. P., Xie, X. \& Chang, S. (2011). Cooperative and competitive orientation among chinese people: scale development and validation. Management and Organization Review, 7, 353-379.

Curry, O. S. (2016). Morality as cooperation: A problem-centred approach. T. K. Shackelford ve R. D. Hansen (Ed.). The evolution of morality içinde. 27-51. UK: Springer International Publishing.

Curry, O. S., Chesters, M. J. \& Van Lissa, C. J. (2019). Mapping morality with a compass: Testing the theory of 'morality as cooperation' with a new questionnaire. Journal of Research in Personality, $78,106-124$.

Çelik Durmuş, S. \& Yıldırım, A. (2016). Adaptation to Turkish of nurse -nurse collaboration scale. Journal of Human Sciences, 13(2), 3521-3528. 
Deutsch, M. (1949a). An experimental study of the effects of cooperation and competition upon group process. Human Relations, 2(3), 199-232.

Deutsch, M. (1949b). A theory of cooperation and competition. Human Relations, 2(2), 129-152.

Deutsch, M. (2006). Cooperation and competition. M. Deutsch, P. T. Coleman ve E. C. Marcus, (Ed.). The handbook of conflict resolution: theory and practise (2. Bask1) içinde. 23-43. UK:Wiley Online Library.

Glasman, L. R. \& Albarracín, D. (2006). Forming attitudes that predict future behavior: A meta-analysis of the attitude-behavior relation. Psychological Bulletin, 132(5), 778-822.

Hamilton, W. D. (1964). The genetical evolution of social behavior. Journal of Theoretical Biology, 7, 152.

Henrich, J. \& Muthukrishna, M. (2020). Tho origins and psychology of human cooperation. Annual Review af Psychology, 1-44.

Jordan, J., Mullen, E. \& Murnighan, J. K. (2011). Striving fort he moral self: The effects of recalling past moral actions on future moral behavior. Personality and Social Psychology Bulletin, 37(5), 701713.

Köse, S., Sayar, K., Ak, İ., Aydın, N., Kalelioğlu, Ü., Kırpınar, İ., Reeves, R. A., Pryzbeck, T. R. \& Cloninger, C. R. (2004). Mizaç ve Karakter Envanteri (Türkçe TCI): geçerlik, güvenirliği ve faktör yapısı. Klinik Psikofarmakoloji Bülteni, 14(3), 107-131.

Kuhn, S. (2019). Prisoner's Dilemma. E. N. Zalta (Ed.) The stanford encyclopedia of philosophy (2019 Kış Baskıs1) içinde. 2 Ocak 2020 tarihinde https://plato.stanford.edu/entries/prisoner-dilemma/ adresinden erişildi.

LaPiere, R. T. (1934). Attitudes vs. actions. Social Forces, 13(2), 230-237.

Hu, L. \& Bentler, P. M. (1999) Cutoff criteria for fit indexes in covariance structure analysis: Conventional criteria versus new alternatives. Structural Equation Modeling: A Multidisciplinary Journal, 6(1), 1-55.

Lu, S., Au, W-T, Jiang, F., Xie, X. \& Yam, P. (2012). Cooperativeness and competitiveness as two distinct constructs: Validating the cooperative and competitive personality scale in a social dilemma context. International Journal of Psychology, 1-13.

Nowak, M. A. \& Sigmund, K. (2005). Evolution of indirect reciprocity. Nature, 437, 1291-1298.

Öztan, N. (1995). Terapist ile hasta arasındaki terapötik ilişkinin farklı boyutlarda incelenmesi. Yayımlanmamış doktora tezi, Ankara Üniversitesi Sosyal Bilimler Enstitüsü, Ankara.

Sachs, J. L., Mueller, U. G., Wilcox, T. P. \& Bull, J. J. (2004). The evolution of cooperation. The Quarterly Review of Biology, 79(2), 135-160.

Schwartz, S. \& Bilsky, W. (1990). Toward a theory of the universal content and structure of values: Extensions and cross-cultural replications. Journal of Personality and Social Psychology, 58, 878891.

Tabachnik, B. G. \& Fidell, L. S. (2007). Using multivariate statistics. Boston: Allyn and Bacon.

Trivers, R. L. (1971). The evolution of reciprocal altruism. Quarterly Review of Biology, 46, 35-57.

West, S. A., Griffin, A. S. \& Gardner, A. (2007). Evolutionary explanations for cooperation review. Current Biology, 17, 661-672.

Xie, X., Yu, Y., Chen, X., \& Chen, X. (2006). The measurement of cooperative and competitive personality. Acta Psychologica Sinica, 38(1), 116-125.

Yeşilkaya, M. (2018). Özgeci davranış olgusuna ilişkin epistemolojik sorunlar üzerine bir inceleme: Siyah, beyaz ve gri. MANAS Sosyal Araştırmalar Dergisi, 7(4), 469-489. 
Y1lmaz, O. \& Bahçekapıl1, H. G. (2016). Supernatural and secular monitors promote human cooperation only if they remind of punishment. Evolution and Human Behavior, 37, 79-84.

Y1lmaz, O., Harma, M. \& Doğruyol, B. (2020). Independent test of morality as cooperation theory in a Turkish sample. Personality and Individual Differences. (Baskida). 